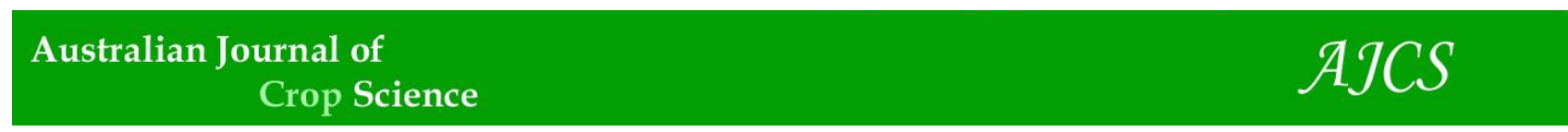

AJCS 12(05):711-716 (2018)

ISSN:1835-2707

doi: $10.21475 /$ ajcs.18.12.05.PNE793

\title{
Integrated management systems for the improvement of the physical-hydric quality of a cerrado oxisol
}

\author{
Leonardo Rodrigues Barros ${ }^{1 *}$, Adriana Aparecida Ribon ${ }^{2}$, Kathleen Lourenço Fernandes ${ }^{3}$, Jéssika Lorrine \\ de Oliveira Sousa ${ }^{1}$, Vladia Correchel ${ }^{1}$, Clarice Backes ${ }^{4}$, Alessandro José Marques Santos ${ }^{4}$, Amanda \\ Romeiro Alves ${ }^{2}$
}

\author{
${ }^{1}$ Department of Soil Science, Agronomy School, Federal University of Goiás, Goiania, GO, Brazil \\ ${ }^{2}$ Department of Soil Science, State University of Goiás, Palmeiras de Goiás, GO, Brazil \\ ${ }^{3}$ State University of São Paulo, Agrarian and Veterinarian Faculty, Jaboticabal, São Paulo, Brazil \\ ${ }^{4}$ State University of Goiás, São Luís de Montes Belos, Goiás, Brazil
}

\section{*Corresponding author: barros.solos@gmail.com}

\begin{abstract}
Degradation of the physical-hydric quality of the soils is one of the great obstacles to agricultural production in this country. Inadequate pasture management is one of the main factors that promote soil degradation, by contrast, some alternative farming practices have emerged. The objective of this work was to study the water retention curve obtained through the Richards chamber method, among other attributes of a Yellow Oxisol under Cerrado, planted with pastures in different integrated management systems: integrated crop-livestock-forestry (ILPF); integrated livestock-forestry (IPF); crop-livestock farming (ILP); Unmanaged pasture (P); Rotated picket (PIQ), and native forest (MN). Attributes such as water retention curve, soil density, macro, microporosity and total porosity, available water capacity and organic matter were evaluated in four soil layers $(0-0.10 \mathrm{~m},-0.20$ $\mathrm{m},-0.30 \mathrm{Me}-0.40 \mathrm{~m})$. It was observed that the water content, given by the water retention curve in the soil, was higher in all layers of the IPF treatment. The results of the other evaluated attributes revealed that integrated management systems have potential to improve the physical and hydric conditions of the soil.
\end{abstract}

Keywords: water availability, soil physical quality, soil pore system, soil conservation systems.

\section{Introduction}

Oxisols cover most of the Brazilian Cerrado area (Ribeiro and Walter, 2008). In the Central-West region of Brazil, some of the Oxisols are covered with pasture grasses associated with the Cerrado biome, and show a certain level of deterioration, with high bulk density values, a lower total porosity and, consequently, low water availability (Ferreira et al., 2010). In order to restore these soils, alternative agriculture methods that maintain the productive capacity of the soil and the keeps the country's economy going have been gaining ground (Kichel et al., 2012), particularly integrated systems that combine the production of forest species, grain crops, forage and beef or dairy cattle, through consortium, succession and/or rotation (Balbino et al., 2012).

Integrated systems are responsible for the upturn of deposition rates of soil organic matter (MOS), providing better aggregation and offering suitable environmental conditions for microbial growth, potentially restoring the physical quality of the soil (Vilela et al., 2003). Stone et al. (2003) affirm that the grass root system, associated with annual and tree species, can help boost the levels of lignin, carboxylic and humic acids in soils, controlling aggregate organization and stability, and thus making them less susceptible to degradation.

The soil, due to the organization of its particles, acts as a water reservoir for plants, whether it originates from rainfall or irrigation. The organization of its solid particles, together with MOS, are responsible for the amount of water stored (Libardi, 2010). The soil pore system can be strongly influenced by the management system adopted. Beutler et al. (2008) argue that the pressure exerted on the soil by external forces decreases soil porosity and increases density, reducing the water holding capacity of the soil. Nonetheless, it is true that this fact varies according to soil texture, in sandy soils, for example, due to a higher proportion of coarse sand, compaction may increase the water holding capacity, and thus the soil texture must be always taken into account in compaction studies.

The water holding capacity of the soil is measured by the soil water retention curve (CRA), represented by a graph obtained from laboratory experiments (Gubiani et al., 2012), and indicates the condition of soil water availability, referring to the soil pore system and density. In this context, the present study aimed at studying the water retention curve obtained using the Richards pressure chamber, and the physical-hydric attributes of a Cerrado 
oxisol, grown alongside pastures under different management systems and native forest.

\section{Results and Discussion}

\section{Soil water retention curves}

Analyzing the water retention curves shown in Figure 1, one can observe the influence of the layer and the different pasture and native forest use and management systems on the behavior of the soil water retention curve. In the ILPF treatment, it was observed that the soil water content only occurred at a tension lower than $0.1 \mathrm{MPa}$, indicating the predominance of macropores in the soil under this management system. The absence of water content at greater voltages indicates the presence of a reduced amount of micropores. Santos (2008) affirms that the pore distribution determines the water retention curve, and observes that in no-tillage systems, due to the greater soil compaction in the superficial layer, there is a predominance of micropores that increase the level of water retention in relation to the conventional system. At lower voltages, the pressure to withdraw water from the samples is lower, as the water easily drains from the macropores (Detex, 2004). In the PIQ treatment (Fig. 1), it was possible to observe water content in higher potentials, which may indicate an increased presence of micropores in relation to the previous treatment, ILPF. Another difference in relation to ILPF was that the layer that displayed the highest water content in all potentials was the $0.30-0.40 \mathrm{~m}$ layer, approximately $0.29 \mathrm{~kg}$ $\mathrm{kg}^{-1}$. The forage species in the PIQ is the Mombasa grass, which grows in clumps, leaving the soil exposed and enhancing the impact of cattle treading and consequently, soil compaction (Fernandes et al., 2014, Imhoff et al., 2000). Another important consideration is that the content of retained water is strongly influenced by the clay content at a voltage higher than $0.2 \mathrm{MPa}$, revealing that the water therein originates from the adsorption process, as described by Demattê (1988). Beutler et al. (2002), studying dystrophic and eutrophic Red Oxisols planted with sugar cane, cotton and wood, also observed the influence of clay in the water retention curve for all the layers evaluated.

In the $\mathrm{P}$ treatment, a greater distance between water retention curves was observed throughout all pressures. Fig. 1 shows that the $0-0.10 \mathrm{~m}$ layer presented lower water content at all pressures and a higher water retention level in the macropores than in the micropores. The results obtained are justified by the fact that it is a degraded pasture, which neither showed a forage production capacity, nor a capacity to recover from emergency pests and diseases, besides, the soil is generally compacted (Vilela et al., 2003).

The ILP treatment showed a similar behavior to that observed in the ILPF treatment for the $0-0.10 \mathrm{~m}$ and 0.10 $0.20 \mathrm{~m}$ layers. The water retention curve in the upper layers only displayed water content at voltages up to $0.015 \mathrm{MPa}$. These findings reveal a higher amount of macropores and a reduced amount of micropores in these layers, or that, in this treatment, most of the soil water is retained in the macropores. A similar result to that observed by Beutler et al. (2002) when studying Red Oxisol planted with cotton, sugar cane and native forest. The IPF treatment showed the highest water content in relation to the previously described treatments for the $0.30-0.40 \mathrm{~m}$ layer. At lower voltages $(0.0001-0.001 \mathrm{Mpa})$, the water content of this layer was around $0.35 \mathrm{~kg} \mathrm{~kg}^{-1}$ and at higher potentials, up to $1.00 \mathrm{MPa}$, around $0.21 \mathrm{~kg} \mathrm{~kg}^{-1}$. MN showed the highest water content values. In the $0.10-0.20 \mathrm{~m} \mathrm{MN}$ layer, a water content of approximately $0.41 \mathrm{~kg} \mathrm{~kg}^{-1}$ was found at lower voltages $(0.0001-0.01 \mathrm{MPa})$ and about $0.19 \mathrm{~kg} \mathrm{~kg}^{-1}$ at higher voltages $(0,1-10 \mathrm{MPa})$. It was observed that the water retention curve in this layer suffered a distortion for higher water content at medium voltages, when compared to other curves, probably because this layer has a greater quantity of easily available water retained in the micropores than adsorbed in the fraction clay. In general, MN was the treatment with the highest water content in all layers evaluated. Considering the pasture use and management systems, the IPF treatment displayed the highest water content at the lowest voltages, and the P treatment showed higher water content values at higher voltages, evidencing a greater degree of microporosity in this system. Marchão et al. (2007), when studying a red oxisol under integrated croplivestock systems and an area under Cerrado, concluded that the water retention curve is an attribute capable of comparing distinct soil management systems, and observed that integrated crop systems influence the physical and hydric conditions when compared with a soil without anthropic influence. Beutler et al. (2002) observed that in addition to management systems, soil texture also influences the water retention curve of dystrophic and eutrophic Red Oxisols. Similar to the findings by Beutler et al. (2008), this study also observed a decrease in water retention values as the voltage increased.

\section{Soil attributes}

Table 1 shows mean DS values in different pasture and native forest management systems forthe evaluated layers. In the ILPF system, DS values displayed an increasing behavior along the evaluated layers, demonstrating the influence of the management system, as it requires the use of machines and implements in the area for planting operations, crop care and phytosanitary treatments, as well as crop harvesting. Lima et al. (2014), studying a Yellow Oxisol, verified that DS was the soil attribute that most directly influenced the resistance to penetration. Therefore, according to the results obtained in the present work, one can infer that ILPF was the most susceptible system to soil compaction, especially in the $0.30-0.40 \mathrm{~m}$ layer, where the highest average SD was observed in the profile evaluated.

In the PIQ, ILP, IPF, MN and P treatments, DS average values did not show significant differences between them for any of the studied layers. Regarding the unfolding of each layer according to the management systems, it was observed that for the 0-0.10 m layer DS average values differed from each other, with MN presenting the lowest average. The ILPF and IPF treatments neither differed statistically from $M N$, nor from the treatments with higher mean values (PIQ, P, ILP), indicating that the management systems used in these treatments help maintain DS levels close to those found in areas without anthropic interference.

Marchão et al. (2007), studying a Cerrado Red Oxisol under an integrated livestock-farming system, observed that 
Table 1. Physical, hydric and chemical attributes of soil layers of the dystrophic cohesive yellow oxisol, according to the managements systems.

\begin{tabular}{|c|c|c|c|c|}
\hline \multirow[t]{2}{*}{ Management system } & \multicolumn{4}{|c|}{ Layer (m) } \\
\hline & $0-0.10$ & $0.10-0.20$ & $0.20-0.30$ & $0.30-0.40$ \\
\hline \multicolumn{5}{|l|}{ Soil density $\left(\mathrm{Kg} \mathrm{m}^{-3}\right)$} \\
\hline ILPF* & $1.43^{* *} a b B$ & $1.65 \mathrm{aAB}$ & $1.68 \mathrm{aAB}$ & $1.78 \mathrm{aA}$ \\
\hline PIQ & $1.64 \mathrm{aA}$ & $1.62 \mathrm{aA}$ & $1.73 \mathrm{aA}$ & $1.58 \mathrm{abA}$ \\
\hline$P$ & $1.69 \mathrm{aA}$ & $1.58 \mathrm{aA}$ & $1.50 \mathrm{abA}$ & $1.56 \mathrm{abA}$ \\
\hline ILP & $1.68 \mathrm{aA}$ & $1.72 \mathrm{aA}$ & $1.69 \mathrm{aA}$ & $1.64 \mathrm{abA}$ \\
\hline IPF & $1.54 \mathrm{abA}$ & $1.69 \mathrm{aA}$ & $1.56 \mathrm{aA}$ & $1.46 \mathrm{bA}$ \\
\hline $\mathrm{MN}$ & $1.34 \mathrm{bA}$ & $1.28 \mathrm{bA}$ & $1.27 \mathrm{bA}$ & $1.41 \mathrm{bA}$ \\
\hline \multicolumn{5}{|l|}{ Total porosity $\left(\mathrm{m}^{3} \mathrm{~m}^{-3}\right)$} \\
\hline ILPF* & $0.32 * * a b A$ & $0.22 \mathrm{bAB}$ & $0.20 \mathrm{bB}$ & $0.20 \mathrm{bB}$ \\
\hline PIQ & $0.25 \mathrm{abA}$ & $0.24 \mathrm{bA}$ & $0.24 \mathrm{bA}$ & $0.33 \mathrm{aA}$ \\
\hline$P$ & $0.24 \mathrm{bA}$ & $0.27 \mathrm{bA}$ & $0.30 \mathrm{abA}$ & $0.29 \mathrm{abA}$ \\
\hline ILP & $0.25 \mathrm{abA}$ & $0.22 \mathrm{bA}$ & $0.24 \mathrm{bA}$ & $0.25 \mathrm{abA}$ \\
\hline IPF & $0.28 \mathrm{abA}$ & $0.24 \mathrm{bA}$ & $0.30 \mathrm{abA}$ & $0.33 \mathrm{abA}$ \\
\hline $\mathrm{MN}$ & $0.37 \mathrm{aA}$ & $0.41 \mathrm{aA}$ & $0.41 \mathrm{aA}$ & $0.35 \mathrm{aA}$ \\
\hline \multicolumn{5}{|l|}{ Macropores $\left(\mathrm{m}^{3} \mathrm{~m}^{-3}\right)$} \\
\hline ILPF* & $0.14 * * a A$ & $0.06 \mathrm{aB}$ & $0.04 \mathrm{aB}$ & $0.04 \mathrm{aB}$ \\
\hline PIQ & $0.03 \mathrm{bB}$ & $0.03 \mathrm{aB}$ & $0.03 \mathrm{aB}$ & $0.10 \mathrm{aA}$ \\
\hline$P$ & $0.04 \mathrm{bA}$ & $0.04 \mathrm{aA}$ & $0.05 \mathrm{aA}$ & $0.05 \mathrm{aA}$ \\
\hline ILP & $0.07 \mathrm{bA}$ & $0.04 \mathrm{aA}$ & $0.04 \mathrm{aA}$ & $0.04 \mathrm{aA}$ \\
\hline IPF & $0.05 \mathrm{bA}$ & $0.03 \mathrm{aA}$ & $0.06 \mathrm{aA}$ & $0.06 \mathrm{aA}$ \\
\hline $\mathrm{MN}$ & $0.09 \mathrm{abA}$ & $0.08 \mathrm{aA}$ & $0.08 \mathrm{aA}$ & $0.05 \mathrm{aA}$ \\
\hline \multicolumn{5}{|l|}{ Micropores $\left(\mathrm{m}^{3} \mathrm{~m}^{-3}\right)$} \\
\hline ILPF* & $0.17^{* *} \mathrm{aA}$ & $0.15 \mathrm{aA}$ & $0.16 \mathrm{aA}$ & $0.16 \mathrm{aA}$ \\
\hline PIQ & $0.22 \mathrm{aA}$ & $0.21 \mathrm{aA}$ & $0.21 \mathrm{aA}$ & $0.23 \mathrm{aA}$ \\
\hline P & $0.19 \mathrm{aA}$ & $0.22 \mathrm{aA}$ & $0.25 \mathrm{aA}$ & $0.23 \mathrm{aA}$ \\
\hline ILP & $0.18 \mathrm{aA}$ & $0.18 \mathrm{aA}$ & $0.20 \mathrm{aA}$ & $0.21 \mathrm{aA}$ \\
\hline IPF & $0.22 \mathrm{aA}$ & $0.20 \mathrm{aA}$ & $0.24 \mathrm{aA}$ & $0.26 \mathrm{aA}$ \\
\hline $\mathrm{MN}$ & $0.27 \mathrm{aA}$ & $0.32 \mathrm{aA}$ & $0.33 \mathrm{aA}$ & $0.30 \mathrm{aA}$ \\
\hline \multicolumn{5}{|c|}{ Available water capacity (CAD) $\left(\mathrm{m}^{3} \mathrm{~m}^{-3}\right)$} \\
\hline ILPF* & $3.92 * *$ bA & $2.77 \mathrm{bA}$ & $3.64 \mathrm{abA}$ & $4.06 \mathrm{aA}$ \\
\hline PIQ & $3.07 \mathrm{bA}$ & $3.18 \mathrm{bA}$ & 3.34 bA & $4.58 \mathrm{aA}$ \\
\hline $\mathrm{P}$ & $4.66 \mathrm{bA}$ & $4.01 \mathrm{bA}$ & $4.74 a b A$ & $4.63 \mathrm{aA}$ \\
\hline ILP & $6.20 \mathrm{abA}$ & $4.54 \mathrm{bAB}$ & $3.76 \mathrm{abB}$ & $5.07 \mathrm{aAB}$ \\
\hline IPF & $7.00 \mathrm{abA}$ & $6.38 \mathrm{abA}$ & $6.45 \mathrm{abA}$ & $6.64 \mathrm{aA}$ \\
\hline $\mathrm{MN}$ & $11.18 \mathrm{aA}$ & $10.11 \mathrm{aAB}$ & $8.54 \mathrm{aBC}$ & $7.22 \mathrm{aC}$ \\
\hline \multicolumn{5}{|c|}{ Organic matter (OM) $\left(\mathrm{g} \mathrm{kg}^{-1}\right)$} \\
\hline ILPF* & $29.33^{* *} \mathrm{cA}$ & $22.33 \mathrm{CAB}$ & $16.33 \mathrm{bB}$ & $13.67 \mathrm{aB}$ \\
\hline PIQ & $31.00 \mathrm{bcA}$ & $21.33 \mathrm{CAB}$ & $15.00 \mathrm{bB}$ & $15.00 \mathrm{aB}$ \\
\hline $\mathrm{P}$ & $67.67 \mathrm{aA}$ & $37.00 \mathrm{abB}$ & $27.67 \mathrm{abBC}$ & $24.00 \mathrm{aC}$ \\
\hline ILP & $43.00 \mathrm{bA}$ & $28.67 \mathrm{bcB}$ & $21.67 \mathrm{abB}$ & $19.00 \mathrm{aB}$ \\
\hline IPF & $32.67 \mathrm{bcA}$ & $18.00 \mathrm{cB}$ & $15.00 \mathrm{bB}$ & $13.33 \mathrm{aB}$ \\
\hline $\mathrm{MN}$ & $63.67 \mathrm{aA}$ & $47.00 \mathrm{aB}$ & $30.67 \mathrm{aC}$ & $22.67 \mathrm{aC}$ \\
\hline
\end{tabular}

*ILPF: Integrated crop-livestock-forestry ; PIQ: Picket; P: Pasture; ILP: Integrated crop-livestock ; IPF: Integrated livestock-forestry; MN: Native forest. **Means followed by the same capital letters on the lines and lower case letters in the column do not differ significantly by the Tukey test at $5 \%$ probability.

pasture management systems lead DS to decrease with soil depth, while cropping systems do not display the same behavior. The authors attribute these differences to a higher level of machinery traffic in cropping areas than in pastures. Regarding PT in ILPF treatment, it was observed that the average values presented significant differences for the evaluated layers. In PIQ, P, ILP, IPF and MN treatments, the means did not present significant differences for any of the studied layers. For the unfolding of each layer underthese management systems, it was noticed that MN presented a higher PT, which differing statistically from the other treatments. P presented the lowest PT mean, and ILPF, PIQ, ILP and IPF treatments showed intermediate means that did not differ statistically from the highest and the lowest means. In rotated pickets with Mombasa grass (PIQ), the mean PT value found in the $0-0.10 \mathrm{~m}$ layer did not differ from the average value found in MN. However, in all other layers and treatments, PT values were lower than those obtained with MN. These results are in consonance with the findings of Neves Neto et al. (2012), who studying the physical and chemical changes of a dystrophic Yellow Oxisol caused by the replacement of the native forest with Mombasa grass, observed that three years after grass introduction, the soil already presented a significant reduction of PT and an increase in DS levels. Lepsch (2011) argues that DS and PT are closely related attributes, since they deal with the relationship between the arrangement of the solid particles of the soil and, therefore, are sensitive attributes, capable of differentiating management systems or even the time in use of a given system (Barbosa et al., 2016, Reicherdt et al., 2007), and they behave in an inversely proportional manner: the lower PT values, the higher the DS values. Spera et al. (2009), when assessing integration systems, found PT values very close to those under the native forest system. Souza et al. (2005), studying Red Oxisol and Quartzarenic Neosol, noticed that PT is higher in clayey soils than in sandy soils.

The averages of the macropores (Table 1) differed between the systems studied only in the $0-0.10 \mathrm{~m}$ layer, where it was observed that ILPF treatment presented a higher mean of macroporosity than those found in the other systems, except in relation to MN. In PIQ treatment, the macroporosity of the $0.30-0.40 \mathrm{~m}$ layer was higher than that observed in the other layers, while in the other systems $(P$, ILP, IPF and MN) the macroporosity did not differ between the layers analyzed. Spera et al. (2009), evaluating the impact of integrated crop-livestock systems, did not observe differences in macroporosity either. On the other hand, 


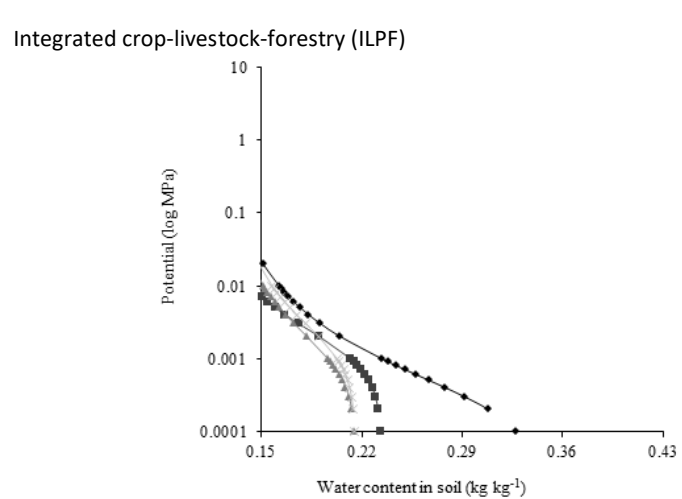

Pasture (P)

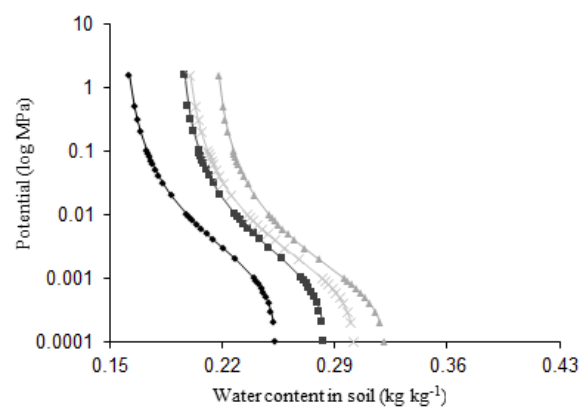

Integrated livestock-forestry (IPF)

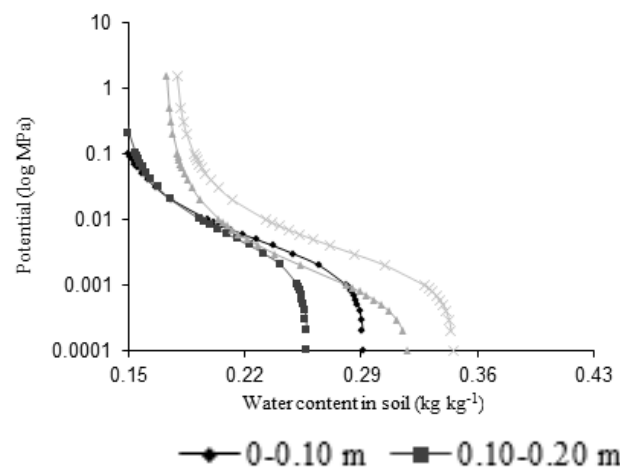

Picket (PIQ)

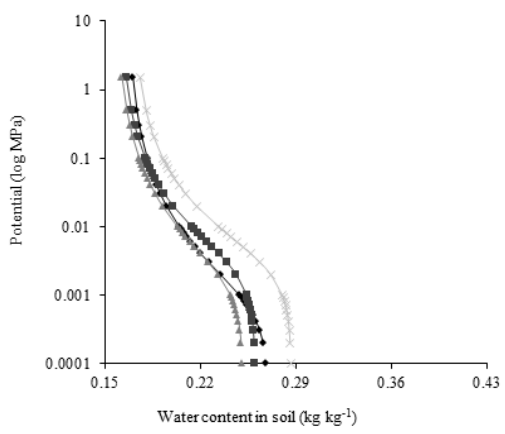

Integrated crop-livestock Integration (ILP)

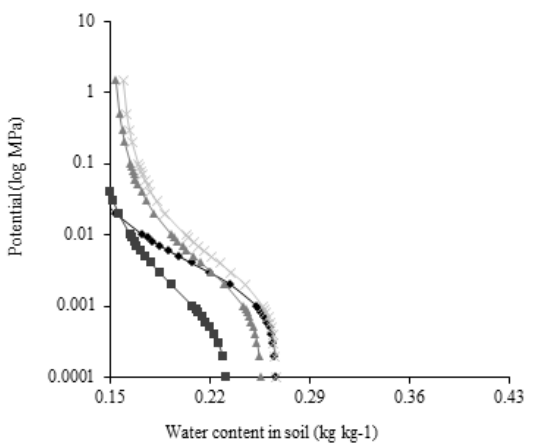

Native Forest (MN)

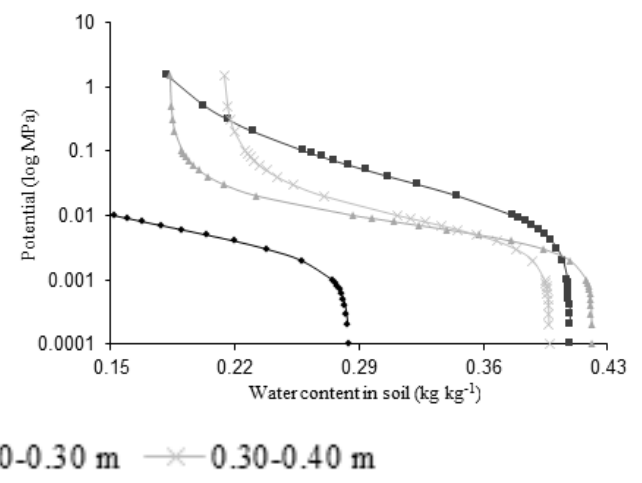

Fig 1. Water retention curve (CRA) in a typical dystrophic cohesive yellow oxisol under different pasture and native forest management systems.

Marchão et al. (2007) observed alterations in the macroporosity of an Oxisol planted with integrated croplivestock-forestry in relation to Cerrado. The authors observed alterations ranging from $80 \%$ to $20 \%$ in the macroporosity levels in comparison with an unchanged soil. Microporosity did not present significant difference in any of the layers evaluated (Table 1). ILPF was the treatment with the lowest amount of micropores. The results were also observed in the CRA. No water content was observed at higher voltages, due to the smaller amount of micropores observed in ILPF. These results are different from those found by Marchão et al. (2007), who studied microporosity in integrated crop-livestock systems and observed that probability of means increased by $5 \%$ in this system when compared with the Cerrado Red Oxisol. In ILPF, PIQ, P and IPF treatments, the mean values of CAD did not differ between the evaluated layers. The mean $C A D$ values differed between the assessed layers in ILP, in which the highest average was observed in the $0-0.10 \mathrm{~m}$ layer, and the lowest in the $0.20-0.30 \mathrm{~m}$ layer. For CAD unfolding, according to the different management systems for each layer, it was possible to observe that $\mathrm{MN}$ presented the highest average in the $0-0.10 \mathrm{~m}$ layer, which differed statistically from the others. In this layer, the mean values of ILPF, PIQ and P presented the lowest mean values, which did not differ between them, but differed from the MN CAD average. The means of CAD in ILP and IPF treatments presented similar values, which did not differ from $M N$ nor from other treatments.

As observed with other variables, DS and PT, IPF treatment showed the highest mean CAD values, without considering $M N$. Another characteristic of this treatment and the CAD variable was that it did not differ statistically from $M N$ in any of the evaluated layers. This finding highlights that IPF was the management system that brought the soil closer to its natural characteristics, observed under MN system.

Beutler et al. (2002), studying eutroferric and dystrophic Red Oxisols, observed that the soils under native forest have 
a higher CAD in relation to soils under cotton and sugar cane plantation systems. According to the authors, the results may be due to the ability of MOS to influence the soil structure, leading to an increase of the CAD rates.

According to the MOS mean values found, the $0-0.10 \mathrm{~m}$ layer showed higher values in all treatments, however, the highest values were observed in $\mathrm{MN}$ treatment, followed by P, ILP, PIQ, IPF and ILPF. In this layer, all the averages were above $29 \mathrm{~g} \mathrm{~kg}^{-1}$ evidencing the benefits of integrated systems and the use of pastures to increase MOS. These results are similar to those obtained by Beutler et al. (2002), reinforcing that integrated systems show a good capacity of MOS deposition, favoring soil structuring. Silva et al. (2017), studying the effects of use and management systems on organic carbon and the physical and hydric attributes of a Yellow Oxisol, observed that the conversion of native Cerrado into no-tillage and pasture systems increased the soil organic carbon content over time.

According to studies carried out by Fidalski and Tormena (2007) in Yellowish-Red Argisol planted with pasture, the organic C content influences DS and, as a consequence, other soil physical attributes can be altered, such as porosity. Salton et al. (2005) observed that integrated systems lead to an intense production and maintenance of straw on the soil, together with the abundant root systems, thus they are excellent tools to improve the soil quality, promoting aggregate stability and a greater sustainability of the productive system, mainly for the center-west Brazilian soils under Cerrado.

\section{Materials and Methods}

\section{Characterization of the area}

The experiment was carried out at the Luz da Vida property, located in the municipality of Campestre, state of Goiás (max. lat. 16 $46,472^{\prime}$ and min. long. $49^{\circ} 44,966^{\prime}$ ), with Cwa climate type, according to the Köppen classification system for the Brazilian mid-west region (subtropical climate/highaltitude tropical climate). The region is topographically composed by mounts and hills, with a weak to strong desiccation profile (SIC, 2006). Analysis of the physical andhydric conditions of the soil as well as the organic matter content were carried out at the Soil Laboratory of the São Paulo State University (UNESP), Jaboticabal Unit, state of São Paulo.

The soil under study was classified as a typical dystrophic cohesive yellow oxisol, clayey in texture (Embrapa, 2013), and the clay, silt and sand values were $357 \mathrm{~g} \mathrm{~kg}^{-1}, 107 \mathrm{~kg}^{-1}$, $536 \mathrm{~g} \mathrm{~kg}^{-1}$, respectively. The cohesive nature was mainly observed in the $A$ and $A / B$ horizon, $0-0.28 \mathrm{~m}$ and $0.28-0.63$ $\mathrm{m}$ depth, respectively (Fernandes et al., 2017).

\section{Characterization of the experiment}

The study of the variables was organized using a randomized complete block design, in which blocks were subdivided into plots, the main treatments corresponded to the five pasture and native forest management systems, and the secondary treatments corresponded to four soil layers $(0-0.1 \mathrm{~m} ; 0.1$ $0.2 \mathrm{~m} ; 0.2-0.3 \mathrm{~m} ; 0.3-0.4 \mathrm{~m}$ ), with three replicates. Each block was approximately $1800 \mathrm{~m}^{2}$. The treatments were organized as follows:
- ILPF: Integrated crop-livestock-forestry area, with eucalyptus in a spacing interval of $3.0 \times 1.5 \mathrm{~m}$ for 6 years, and implementation of the soybean-brachiaria consortium in "Barreirão" and Brachiaria decumbens system after soybean harvest;

- IPF: Integrated livestock-forestry area, with eucalyptus and brachiaria grass (Brachiaria decumbens) in spacing intervals of $3.0 \times 1.5 \mathrm{~m}$, for 6 years;

- ILP: 8-year-old soybean sowing area under conventional tillage after grass desiccation (Brachiaria decumbens) and corn farming after soybean harvest;

- P: A 8-year-old pasture area with brachiaria grass (Brachiaria decumbens) for livestock grazing;

- PIQ: Rotated picket with Mombasa grass for livestock grazing.

- $\mathrm{MN}$ : native forest (natural permanent preservation area);

\section{Data collection}

To perform the extraction of undisturbed samples, aluminum rings with a cutting edge and an internal volume of approximately $50 \mathrm{~cm}^{3}$ were used to measure the soil water retention curve using the Richards chamber method. The undisturbed samples were saturated in a plastic tray filled with water during a $24 \mathrm{~h}$-period.

After collection, the samples were prepared to determine water retention curves according to two parameters: gravimetric water $\left(\mathrm{g} \mathrm{g}^{-1}\right)$ and matric potential (MPa). In order to obtain the water retention curve through the Richards pressure chamber, the soil water content was determined using the Richards pressure chamber and a porous plate (Klute, 1986). Different voltages, $0.001 ; 0.003$; $0.006 ; 0.01 ; 0.033 ; 0.06 ; 0.10$ and $0.3 \mathrm{Mpa}$, were applied, obtaining the soil water retention curve for the samples collected. The samples were used to quantify the water content retained in each voltage (Blake and Hartge, 1986), soil density (DS), microporosity through drying (voltage of $0.006 \mathrm{MPa})$, total porosity, according to Danielson and Sutherland (1986), and macroporosity calculated as the difference between total porosity and microporosity. Soil organic matter (MOS) was determined through the organic carbon content, which was obtained by the organic matter wet oxidation with potassium dichromate in sulfuric medium and/or heating (Embrapa, 2011).

\section{Data analysis}

The adjustment of the soil water retention curve was performed using the Van Genuchten mathematical model (1980). Soil properties were evaluated by the Tukey test at a $5 \%$ probability level, using the ASSISTAT statistical software.

\section{Conclusion}

The attributes studied, CRA, DS, PT, macro and micropores and CAD are capable of indicating the physical and hydric conditions of the typical dystrophic cohesive yellow oxisol under different pastures and native forest management systems. 
Changes in the natural vegetation influenced the physical and hydric attributes and CRA of the typical dystrophic cohesive yellow oxisol under the conditions studied.

\section{Acknowledgements}

The authors thank the State University of Goiás (UEG).

\section{References}

Balbino LC, Kichel AN, Bungenstab DJ, Almeida RG (2012) Sistemas de integração: o que são, suas vantagens e limitações. In: BUNGENSTAB, D. J. Sistemas de integração lavoura pecuária floresta. 2:12-18.

Barbosa LR, Nunes LAPL, Araújo ASF, Silva FR, Ibiapina TVB (2016) Penetration resistance and density of a yellow Oxissol under conventional management at different ages. Bioscience J. 32:115-122.

Beutler AN, Centurion JF, Souza ZM, Andrioli I, Roque CG (2002) Retenção de água em dois tipos de Latossolos sob diferentes usos. Revista Brasileira de Ciência do Solo. 26:829-834.

Beutler A, Freddi O, Leone C, Centurion J (2008) Densidade do solo relativa e parâmetro " $\mathrm{S}$ " como indicadores da qualidade física para culturas anuais. Revista de Biologia e Ciências da Terra. 8:27-36.

Danielson RE, Sutherland PL Porosity (1986) In: Klute, A. Methods of soil analysis. 2. ed. Madison: American Society of Agronomy,. part 1, p. 443-461.

Demattê JLI (1988) Manejo de solos ácidos dos trópicos úmidos região amazônica. Campinas: Fundação Cargil, 215p.

Dexter AR (2004) Soil physical quality. Part II. Friability, tillage, filth and hard-setting. Geoderma. 120: 215-225.

Embrapa (2011) Manual de métodos de análise de solos. Rio de Janeiro: Embrapa solos, $230 \mathrm{p}$.

Embrapa (2013) Sistema brasileiro de classificação de solos. 3ed. Brasília: EMBRAPA, 353p.

Fernandes KL, Ribon AA, Hermógenes VTL, Custódio GD, Barros LR (2014) Atributos físicos de solo sob cerrado em diferentes sistemas de uso e manejo de pastagens e mata nativa. Cultivando o Saber. 7:14-27.

Ferreira MM Caracterização física do solo (2010) In: Van Lier, Q. de J. Física do solo. Viçosa: Sociedade Brasileira de Ciência do solo, p. 01-27.

Fidalski J, Tormena CA (2007) Funções de pedontransferência para as curvas de retenção de água e de resistência do solo a penetração em sistemas de manejo com plantas de cobertura permanente em citros. Ciência Rural. 37:13161322.

Gubiani PI, Reichert JM, Campbell C, Reinert DJ, Gelain, NS (2012) Assessing errors and accuracy in dew-point potentiometer and pressure plate extractor measurements. Soil Science of America Journal. 77:19-24.

Imhoff S, Silva AP, Tormena CA (2000) aplicações da curva de resistencia no controle da qualidade física de um solo sob pastagem. Pesquisa Agropecuária Brasileira. 35:1493-1500.

Kichel NA, Balbino LC, Bungenstab DJ, Almeida RG (2012) Sistemas de integração lavoura pecuária floresta. In: Bungenstab, D. J. Sistemas de integração lavoura pecuária floresta. 2:2-9.

Klute A (1986) Water retention: laboratory methods. In: Klute, A. Methods of soil analisys. 2.ed. Madison: American Society of Agronomy,. p 635-662.

Lepsch IF (2011) 19 lições de Pedologia. São Paulo: Oficina de Textos, 2011, $456 \mathrm{p}$.
Libardi PL (2010) Água no solo (In: Van Lier, Q. de J. Física do solo. Viçosa: Sociedade Brasileira de Ciência do solo, p. 103152.

Lima RP, Silva AR, Oliveira DMS (2014) Análise de trilha de atributos físicos na resistência à penetração de um Latossolo amarelo. Revista de Agricultura Neotropical. 1:65-74.

Marchão RL, Balbino LC, Silva EM, Junior JDGS, Sá MAC, Vilela L, Becquer T (2007) Qualidade Física de um Latossolo Vermelho sob Sistemas de Integração Lavoura-pecuária no Cerrado. Pesquisa Agropecuária Brasileira. 42:873-882.

Neves Neto DN, Santos AC, Silva Neto SP (2012) Atributos físicos e químicos em ecossistema de capim Mombaça na Amazônia Oriental. Revista Ciências Agrarias. 55:75-84.

Reichert JM, Suzuki LEAS, Reinert DJ (2007) Compactação do solo em sistemas agropecuário e florestais: identificação, efeitos, limites críticos e mitigação. In: Klauberg Filho, 0 . Mafra AL, Gatiboni LC Tópicos em ciências do solo. 1:49-134.

Ribeiro JF, Walter BMT (2008) As Principais Fitofisionomias do Bioma Cerrado. In: Sano SM, Almeida SP, Ribeiro JF Cerrado, Ecologia e Flora. 2 v. Brasília, DF: Embrapa Informações Tecnológicas.

Salton JC, Mielniczuk J, Bayer C, Fabricio AC, Macedo MCM, Broch DL, Boeni M, Conceição PCM (2005) Matéria orgânica do solo na integração lavoura-pecuária em Mato Grosso do Sul. Embrapa: Dourados.

Santos R (2008) Propriedades de retenção e condução de água em solos, sob condições de campo e em forma de agregados, submetidos aos plantios convencional e direto. 2008. $102 \mathrm{f}$ Dissertação (Mestrado) - Curso de Ciências, Departamento de Física, Universidade Estadual de Ponta Grossa, Ponta Grossa,

Sic-Goiás. Superintendencia de Geologia e Mineração. Unidades Geomorfológicas. 2006. Disponível em: <http://www.sieg.go.gov.br/rgg/apps/siegdownloads/index. $\mathrm{html}$. Acesso em: 11 de abril de 2017.

Silva RF, Santos GG, Nóbrega JCA, Oliveira GCE, Dias BO, Santos DP, Silva Júnior JP (2017) Impacts of land-use and management systems on organic carbon and water-physical properties of a Latossolo Amarelo (Oxisol). Semina: Ciências Agrárias. 38:109-124.

Souza ED, Carneiro, MAC, Paulino HB (2005) Atributos físicos de um Neossolo Quartzarênico e um Latossolo Vermelho sob diferentes sistemas de manejo. Pesquisa Agropecuária Brasileira. 40: 1135-1139.

Spera S, Pereira H, Fontaneli R, Tomm G (2009) Integração lavoura e pecuária e os atributos físicos de solo manejado sob sistema plantio direto. Revista Brasileira de Ciência do Solo. 33:129-136.

Stone LF, Moreira JAA, Kluthcouski J (2003) Influência das pastagens na melhoria dos atributos físicos-hídricos do solo. In: Klusthcoucki, J.; Stone, L. F.; Aidar, H. Integração LavouraPecuária. 1:143-181.

Van Genuchten MTH (1980) A closed form equation for predicting hydraulic conductivity of unsaturated soils. Soil Sci Society American J. 44:892-898.

Vilela et al. (2003) Benefícios da Integração Lavoura Pecuária. In: Klusthcoucki, J.; Stone, L. F.; Aidar, H. Integração LavouraPecuária. 1ed. Santo Antônio de Goiás: Embrapa Arroz e Feijão. p.143-181. 